\title{
EQUiLIBRIUM
}

Quarterly Journal of Economics and Economic Policy

2015 VOLUME 10 ISSUE 3, September

p-ISSN 1689-765X, e-ISSN 2353-3293

www.economic-policy.pl

Bieszk-Stolorz, B. \& Markowicz, I. (2015). Influence of Unemployment Benefit on Duration of Registered Unemployment Spells. Equilibrium. Quarterly Journal of Economics and Economic Policy, 10(3), pp. 167-183, DOI: http://dx.doi.org/10.12775/ EQUIL.2015.031

\author{
Beata Bieszk-Stolorz, Iwona Markowicz* \\ University of Szczecin, Poland
}

\section{Influence of Unemployment Benefit on Duration of Registered Unemployment Spells}

JEL Classification: $C 01 ; C 14 ; J 64 ; J 65 ; A 11 ; A 14 ; B 16$

Keywords: Kaplan-Meier estimator; Cox hazard model; hazard ratio; unemployment

\begin{abstract}
The purpose of the article is to present the analysis of the influence of unemployment benefit on the duration of registered unemployment spells. The authors made a hypothesis that the very fact of receiving the benefit extends the job seeking time and determines the intensity of unemployment exit. The power of this influence varies depending on a subgroup the unemployed person belongs to. The study was conducted on the basis of data from the Poviat Labour Office in Sulecin. The data were collected as a part of the European Union project implementation. The analysis covered two periods of time - before and after Poland's accession to the European Union and the subsequent changes in legal regulations concerning unemployment benefits. The authors observed separate cohorts of the unemployed registered in 2001 and 2005. The closing dates of the observations were: the end of 2003 and 2007, respectively. Also, the authors examined whether the EU projects implemented after 2004 had an effect on the length of the unemployment spells as well as on the intensity of the unemployment exit. The study confirmed the research hypotheses. The fact of claiming the unemployment benefit prolonged the unem-
\end{abstract}

(C) Copyright Institute of Economic Research \& Polish Economic Society Branch in Toruń

Date of submission: March 1, 2015; date of acceptance: June 13, 2015

*Contact: beatus@wneiz.pl, iwona.markowicz@wneiz.pl, University of Szczecin, Mickiewicza 64, 71-101 Szczecin, Poland 
ployment spells in both periods of observation. The loss of the right to the benefit increased the probability of de-registration in each sub-group.

\section{Introduction}

The influence of benefits, threshold salary and education on the unemployment duration is explained by the job search theory ${ }^{1}$ which refers to certain principles followed by individuals in the process of job seeking. The job search theory represents a microeconomic approach. Its counterpart in the modern macroeconomic thought is a matching theory also called the search and matching theory ${ }^{2}$. Nickell (1979), Hughes and Perlman (1984) showed that the increase in unemployment benefits lead to extended spells of job seeking. The power of this interrelation is weakening as unemployment spells are getting longer.

The purpose of this paper is to analyse the influence of unemployment benefit on the duration of registered unemployment spells. The study was conducted on the basis of data from the Poviat Labour Office in Sulęcin obtained under the European Union project ${ }^{3}$. The analysis covered two periods of time: before and after Poland's accession to the European Union and the change in terms of granting unemployment benefits (Act on promotion of employment and labour market institutions of 20 April 2004). The authors observed separate cohorts of the unemployed who had been registered in 2001 and 2005. The observations were completed by the end of 2003 and 2007, respectively. In the paper the following hypotheses are made: the fact of receiving the benefit by an unemployed person extends their job seeking spell and affects the intensity of their unemployment leaving; the implementation of the EU projects after 2004 has influenced the duration of unemployment spells. The effect of this influence varies among the sub-groups defined according to the categories of job-seekers' attributes. In this study the authors used the following methods to conduct the survival analysis: the Kaplan-Meier estimator and the Cox model of nonproportional hazards.

\footnotetext{
${ }^{1}$ The Nobel Prize winner of 1982 is regarded as the founder of the search theory.

${ }^{2}$ Noble Prize winners of 2001, Diamond, Mortensen and Pissarides contributed to the development of the search and matching theory and to its popularization in the job market analysis.

${ }^{3}$ The project The Analysis and Diagnosis of the Problem of Long-term Unemployment in the Poviat of Sulęcin (Analiza i diagnoza problemu dtugotrwatego bezrobocia w powiecie sulęcińskim), implemented as a part of the Operational Programme Human Capital 20072013.
} 


\section{Literature Review}

The job search theory explains why the unemployed individuals delay their employment decisions and extend their unemployment spell. The spells of frictional unemployment are the subject of the job search theory as well as of the search and matching theory, with both theories focusing on the demand issues. There are plenty of studies confirming the two theories.

Meyer (1990) investigated the impact of the unemployment benefit amount and duration on the duration of unemployment spells. He was particularly interested in the analysis of events occurring in the period before the termination of the unemployment benefit. He found out that higher benefits had a strong negative influence on the likelihood of unemployment exit. This likelihood significantly rises towards the end of the period when the benefit is drawn. Meyer applied the methods for hazard function estimation and compared them with the methods that had been widely used before, e.g. the Weibull model. He also discovered that the parametric approach gave more reliable estimations. The data came from the $\mathrm{CWBH}$ database and concerned males from twelve US states observed between 1978 and 1983 (3365 observations). Their advantage was that they provided accurate information about the subjects' wages received in a week prior to unemployment and about the claimed benefits. Their disadvantage was that the available information was restricted to the time when benefits were received. The data concerning the unemployment period upon the benefit termination were considered censored. Meyer pointed to a high replacement rate amounting to 0.70 (the ratio of the average benefit to the average income earned before the unemployment spell). The empirical hazard defined the ratio of the number of unemployment exits over a given week to the number of the unemployed at the beginning of this week. High intensity was observed in the first few weeks, then between the 25th and 29th week, to be followed by the increase between the 35th and 38th week. Meyer attributed those intensity fluctuations to the period when benefit spells came to an end. His conclusions concerning the application of the model of proportional hazards included the finding that the $10 \%$ increase of unemployment benefits was associated with the $8.8 \%$ drop in the intensity of unemployment leaving. The obtained results referred solely to the period when the benefits were granted. According to Mortensen (1977), higher benefits may lead to stronger intensity in this period, while Katz (1986) claimed that the intensity of unemployment leaving was rising towards the end of benefit spells. 
Han and Hausman (1990) conducted their study basing on the PSID database. It covered 1055 observations of breadwinners aged 20 to 65 . They indicated a large number of unemployment exits in the 26th and 39th week, i.e the moments when benefit spells came to an end in various American states. What is interesting, the intensity of unemployment exits was strong also at the beginning of benefit spells. The authors divided the group of the observed subjects into those who had found new employers and those who had returned to their previous employers. It turned out that job seekers who terminated their unemployment spells early were those who were re-hired by their former employer, even though they had been granted the unemployment benefits. In the case of the former group the unemployment exit intensity did not increase until the end of their benefit spells.

Røed and Zhang (2003) did research into the effect of the benefit amount on the intensity of finding a job by people under 60 who had lost their full-time jobs in 1990 and did not qualify to be granted the unemployment benefit. The observation covered 103 thousand people. Those of them whose benefit spells ended and who did not find a new job were considered censored. Røed and Zhang proved that the benefit amount had a negative effect on the unemployment exit intensity, especially in the case of unemployed males. However, the threat of losing the benefit prompted the unemployed job seekers (mainly women) to find a job. The researchers pointed out that the unemployment exit intensity was rising by $60 \%$ (women) and $40 \%$ (men) at the end of their benefit spells. What is more, Røed and Zhang found out that the unemployment spells varied depending on the benefit size: a $10 \%$ reduction reduced the job seeking time by 1 month in the case of men and by 1-2 weeks in the case of women.

This article is in line with the trend in the modern reference literature, which is the measurement of the unemployment benefit effects on the length of unemployment spells (Moffitt, 1985; Katz \& Meyer, 1990; Hunt, 1995; Card \& Levine, 2000; Hahn at al., 2001; Lalive, 2007). Unemployment brings negative effects to both the national economy and the wellbeing of households. This is why governments can and should use adequate tools to alleviate these effects, focusing in particular on the duration of unemployment. Unfortunately, there are no ready-made solutions to the problem. Both the unemployment rates and its mean duration vary from country to country, disregarding their development level. Governments offer diverse forms of support and activation programmes directed to the unemployed citizens in general as well as to their specific groups. The outcomes of individual programmes can be difficult to predict. Therefore, it seems essential to conduct studies on the effectiveness of these tools. One of the researchers dealing with this issue was Lalive (2007) whose interest- 
ing study focused on the possible effect of extending the unemployment benefit from 30 to as many as 209 weeks. Such an extended benefit was introduced by the Austrian government in 1988 and it targeted at the unemployed 50+ who had been residents of the selected regions for at least six months and who had been employed before. Obviously, such extension of the unemployment benefit resulted in the prolonged unemployment spells, especially in the case of women, which was due to the opportunity of their early retirement. In the reference literature authors often point out that the maximum length of unemployment benefits is strongly correlated with structural unemployment (Nickell \& Layard, 1999). The extended benefit time usually discourages the beneficiaries from job-seeking, thus leading to prolonged unemployment spells. For this reason, it is important to address support programmes to carefully selected groups of beneficiaries. In his research Lalive used the nonlinear regression model in its sharp form, with the thresholds of age eligibility and of distance to danger area border. Szmieder, von Wachter and Bender (2012) applied the nonlinear regression models with several age thresholds to study the effect of the potential benefit duration on the unemployment time throughout the whole economic cycle of 1980-2008 in Germany. The authors pointed out that they had based their research on the model of job-seeking with limitations to liquidity and that the German system of unemployed benefits was ideal for that kind of studies. They adopted the age thresholds reflecting the potential benefit duration as the non-linearity thresholds (42, 44 and 49).

\section{Methodology of Research}

In this study the authors used the following methods to conduct the survival analysis: the Kaplan-Meier estimator (the curves of surviving in unemployment, the identification of hazards proportionality, the average time of unemployment spells, the intensity (hazard) of unemployment leaving) and the Cox model of non-proportional hazards (the relative intensity, or relative hazard, of unemployment exit). Kaplan and Meier (1958) proposed the way of estimating the survival function in the case of censored data: 


$$
\hat{S}\left(t_{i}\right)=\prod_{j=1}^{i}\left(1-\frac{d_{j}}{n_{j}}\right), \text { for } i=1, \ldots, k
$$

where:

$t_{i}$ - the moment when at least one event occurred (deregistering),

$d_{i}$ - the number of events in the time $t_{i}$,

$n_{i}$ - the number of units under observation in the time $t_{i}$.

The hazard (the intensity of deregistering from PLO) was estimated by means of the formula:

$$
h_{j}=\frac{d_{j}}{n_{j}}
$$

where:

$d_{j}-$ the number of deregistered subjects in a given month,

$n_{j}-$ the number of the unemployed subjects under observation at the beginning of that month.

The relative intensity of registered unemployment exit was evaluated by means of the model of non-proportional hazards ${ }^{4}$ (following the recognition of the absence of non-proportionality on the basis of the course of survival curves) in a form:

$$
h(t, Z)=h_{0}(t) \exp (\beta Z+\delta Z \times g(t))
$$

where:

$$
\begin{gathered}
g(t)= \begin{cases}0 & \text { for } t<t_{0} \\
1 & \text { for } t \geq t_{0}\end{cases} \\
Z= \begin{cases}0 & \text { no benefit } \\
1 & \text { benefit }\end{cases}
\end{gathered}
$$

\footnotetext{
${ }^{4}$ See more on the Cox non-proportional hazard model in (Bieszk-Stolorz \& Markowicz, 2012, Bieszk-Stolorz, 2013).
} 
In the model (3) the parameter $\beta$ defines the influence of the exogenous variable on intensity, while the parameter $\delta$ indicates if this influence changes over time ${ }^{5}$. The value $\exp (\beta)$ is understood as the relative intensity (hazard ratio) of deregistration by the unemployed individuals with the right to the benefit in relation to the job seekers deprived of this benefit who have left the labour office register within the period of time shorter than $t_{0}$. The value $\exp (\beta+\delta)$ is a relative intensity in the case when the unemployment spell is longer than $t_{0}$.

\section{Data}

In the study the authors used individual data of 2799 unemployed individuals registered in 2001 and 3377 ones registered in 2005 by the Poviat Labour Office in Sulęcin. The sizes of sub-groups can be found in Table 1. The individuals considered to be censored were those who remained registered by the end of the observation, i.e. who failed to leave unemployment.

Table 1. Number of the observed unemployed according to their attributes and the fact of claiming the benefit

\begin{tabular}{|l|c|c|c|c|c|c|c|c|}
\hline \multirow{2}{*}{ Groups } & \multicolumn{4}{|c|}{$\mathbf{2 0 0 1 - 2 0 0 3}$} & \multicolumn{4}{|c|}{$\mathbf{2 0 0 5 - 2 0 0 7}$} \\
\cline { 2 - 9 } & benefit & $\begin{array}{c}\text { no } \\
\text { benefit }\end{array}$ & total & censored & benefit & $\begin{array}{c}\text { no } \\
\text { benefit }\end{array}$ & total & $\begin{array}{c}\text { censo- } \\
\text { red }\end{array}$ \\
\hline Total & 1425 & 1374 & 2799 & 413 & 1146 & 2231 & 3377 & 96 \\
\hline $\mathrm{K}$ & 519 & 550 & 1069 & 188 & 434 & 950 & 1384 & 49 \\
\hline $\mathrm{M}$ & 906 & 824 & 1730 & 225 & 712 & 1281 & 1993 & 47 \\
\hline $\mathrm{W}_{1}$ & 390 & 453 & 843 & 94 & 319 & 695 & 1014 & 8 \\
\hline $\mathrm{W}_{2}$ & 388 & 370 & 758 & 98 & 352 & 665 & 1017 & 29 \\
\hline $\mathrm{W}_{3}$ & 356 & 340 & 696 & 122 & 209 & 436 & 645 & 19 \\
\hline $\mathrm{W}_{4}$ & 281 & 202 & 483 & 94 & 240 & 376 & 616 & 32 \\
\hline $\mathrm{S}_{1}$ & 336 & 399 & 735 & 134 & 252 & 618 & 870 & 36 \\
\hline $\mathrm{S}_{2}$ & 645 & 654 & 1299 & 200 & 475 & 961 & 1436 & 37 \\
\hline $\mathrm{S}_{3}$ & 74 & 57 & 131 & 19 & 75 & 107 & 182 & 4 \\
\hline $\mathrm{S}_{4}$ & 326 & 225 & 551 & 53 & 295 & 451 & 746 & 16 \\
\hline $\mathrm{S}_{5}$ & 44 & 39 & 83 & 7 & 49 & 94 & 143 & 3 \\
\hline $\mathrm{W}_{5}$ &
\end{tabular}

Women (K), Men (M); Age: 18-24 ( $\left.\mathrm{W}_{1}\right), 25-34\left(\mathrm{~W}_{2}\right), 35-44\left(\mathrm{~W}_{3}\right), 45-54\left(\mathrm{~W}_{4}\right)$; Education: lower secondary, primary and incomplete primary $\left(\mathrm{S}_{1}\right)$, basic vocational $\left(\mathrm{S}_{2}\right)$, general secondary $\left(\mathrm{S}_{3}\right)$, post-secondary and vocational secondary $\left(\mathrm{S}_{4}\right)$, tertiary $\left(\mathrm{S}_{5}\right)$

Source: own study based on the data from the Poviat Labour of Sulęcin.

\footnotetext{
${ }^{5}$ Estimation method - the partial likelihood.
} 


\section{4}

Beata Bieszk-Stolorz, Iwona Markowicz

\section{The Effect of Unemployment Benefit on the Job Seeking Process - Study Results}

For both the periods of observation the authors determined the KaplanMeyer estimators that were used to compare the probabilities of leaving the register by the individuals who were claiming the benefit and by those who did not, in total (Figure 1) and in the sub-groups. In the first months of unemployment we can clearly see the difference in the survival models constructed for the unemployment benefit recipients and for those who were not granted the benefit. It means the absence of hazard proportionality in those groups. A similar shape of the survival curves could be seen in the sub-groups discriminated according to gender, age and education.

Figure. 1. Kaplan-Meier estimators for unemployed persons in 2001-2003 and 2005-2007 total
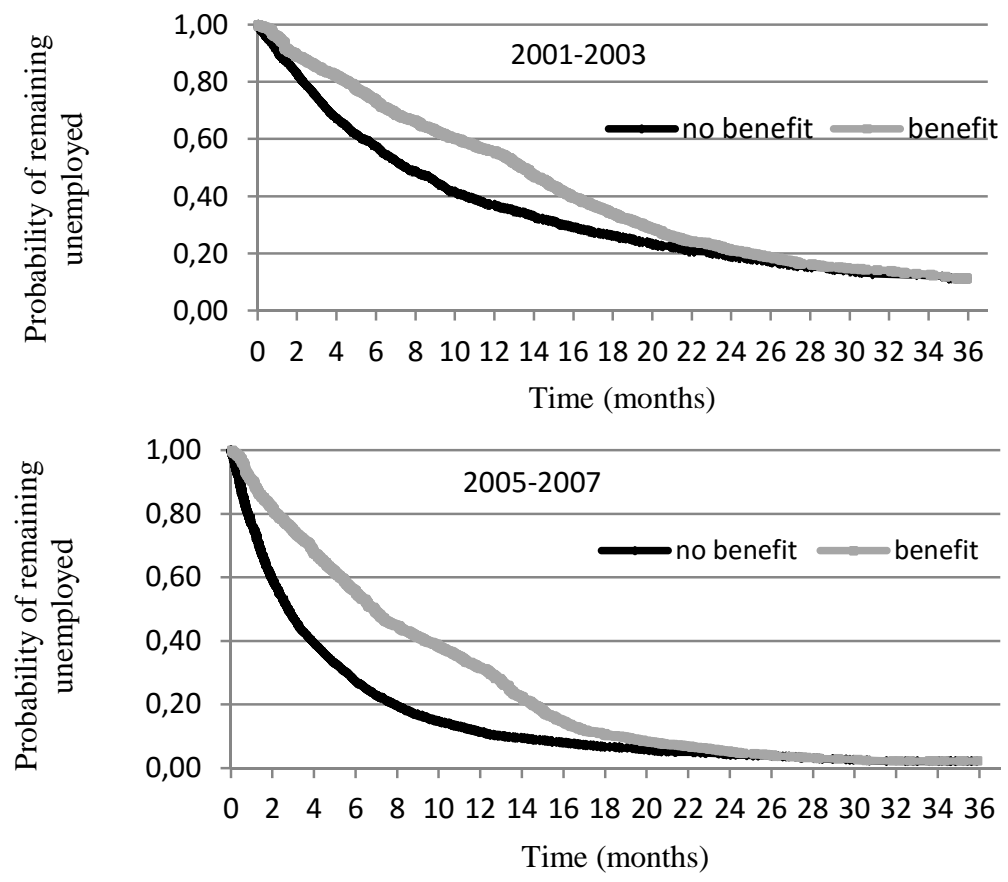

Source: own study based on the data from the Poviat Labour of Sulęcin. 
Table 2. Mutual distance measures determined basing on the estimator for the unemployment spell duration for the unemployed registered in 2001. The observation by the end of 2003 .

\begin{tabular}{|l|c|c|c|c|c|c|}
\hline \multirow{2}{*}{ Groups } & $\begin{array}{c}\text { First } \\
\text { quartile }\end{array}$ & Median & $\begin{array}{c}\text { Third } \\
\text { quartile }\end{array}$ & $\begin{array}{c}\text { First } \\
\text { quartile }\end{array}$ & Median & $\begin{array}{c}\text { Third } \\
\text { quartile }\end{array}$ \\
\cline { 2 - 7 } & \multicolumn{5}{|c|}{ benefit } \\
\hline Total & 5.63 & 13.41 & 21.49 & 2.96 & 7.53 & 18.94 \\
\hline $\mathrm{K}$ & 5.95 & 13.81 & 24.79 & 2.55 & 7.13 & 19.82 \\
\hline $\mathrm{M}$ & 5.54 & 13.18 & 20.45 & 3.29 & 7.59 & 18.54 \\
\hline $\mathrm{W}_{1}$ & 5.64 & 13.32 & 19.55 & 2.19 & 6.26 & 15.28 \\
\hline $\mathrm{W}_{2}$ & 5.62 & 13.35 & 21.17 & 2.76 & 6.12 & 16.18 \\
\hline $\mathrm{W}_{3}$ & 6.54 & 13.78 & 22.52 & 3.91 & 9.90 & 24.65 \\
\hline $\mathrm{W}_{4}$ & 4.91 & 13.53 & 24.76 & 3.65 & 10.03 & 21.04 \\
\hline $\mathrm{S}_{1}$ & 6.94 & 14.83 & 24.10 & 3.51 & 8.86 & 22.90 \\
\hline $\mathrm{S}_{2}$ & 5.93 & 13.76 & 22.74 & 2.89 & 7.50 & 19.02 \\
\hline $\mathrm{S}_{3}$ & 4.09 & 8.25 & 19.97 & 3.67 & 7.53 & 16.61 \\
\hline $\mathrm{S}_{4}$ & 4.73 & 11.61 & 19.07 & 2.17 & 5.31 & 13.96 \\
\hline $\mathrm{S}_{5}$ & 2.40 & 10.78 & 17.69 & 2.41 & 6.61 & 14.56 \\
\hline
\end{tabular}

Source: own study based on the data from the Poviat Labour of Sulęcin.

Table 3. Mutual distance measures determined basing on the estimator for the unemployment spell duration for the unemployed registered in 2005. The observation by the end of 2007.

\begin{tabular}{|l|r|r|r|r|r|r|}
\hline \multirow{2}{*}{ Groups } & \multicolumn{1}{c|}{$\begin{array}{c}\text { First } \\
\text { quartile }\end{array}$} & \multicolumn{1}{c|}{ Median } & \multicolumn{1}{c|}{$\begin{array}{c}\text { Third } \\
\text { quartile }\end{array}$} & \multicolumn{1}{c|}{$\begin{array}{c}\text { First } \\
\text { quartile }\end{array}$} & Median & \multicolumn{1}{c|}{$\begin{array}{c}\text { Third } \\
\text { quartile }\end{array}$} \\
\cline { 2 - 7 } & \multicolumn{3}{|c|}{ benefit } & \multicolumn{3}{|c|}{ no benefit } \\
\hline Total & 2.96 & 6.90 & 13.35 & 1.12 & 2.76 & 6.48 \\
\hline $\mathrm{K}$ & 2.73 & 7.17 & 13.97 & 0.82 & 2.27 & 5.93 \\
\hline $\mathrm{M}$ & 3.02 & 6.58 & 13.08 & 1.28 & 3.16 & 6.90 \\
\hline $\mathrm{W}_{1}$ & 2.23 & 5.41 & 10.95 & 1.08 & 2.32 & 5.14 \\
\hline $\mathrm{W}_{2}$ & 2.89 & 6.90 & 13.35 & 1.13 & 2.75 & 6.09 \\
\hline $\mathrm{W}_{3}$ & 2.21 & 7.12 & 13.75 & 1.05 & 2.83 & 6.90 \\
\hline $\mathrm{W}_{4}$ & 4.27 & 8.98 & 15.62 & 1.12 & 3.78 & 9.21 \\
\hline $\mathrm{S}_{1}$ & 3.78 & 8.12 & 14.76 & 1.28 & 3.22 & 7.41 \\
\hline $\mathrm{S}_{2}$ & 2.75 & 6.05 & 12.90 & 1.09 & 2.89 & 6.67 \\
\hline $\mathrm{S}_{3}$ & 2.50 & 7.25 & 12.43 & 0.82 & 1.82 & 4.37 \\
\hline $\mathrm{S}_{4}$ & 3.70 & 7.22 & 13.82 & 0.89 & 2.27 & 5.38 \\
\hline $\mathrm{S}_{5}$ & 2.05 & 5.77 & 10.99 & 1.08 & 2.27 & 4.55 \\
\hline
\end{tabular}

Source: own study based on the data from the Poviat Labour of Sulęcin. 
When analysing the results in Tables 2 and 3, we have come to the following conclusions:

a) referring to the unemployed registered in 2001 :

- $25 \%$ of the benefit recipients were deregistered after 5.6 months of job seeking, 505 - after 13.4 months, and $75 \%$ - after 21.5 months,

- $25 \%$ of those who were not entitled to the benefit got deregistered after 3 months of job seeking, $50 \%$ - after $7.5 \%$, and $75 \%$ after 18.9 months,

- in the group of benefit recipients it was men who deregistered sooner, while in the group of the unemployed not entitled to the benefit women left the register earlier than men,

- generally speaking, younger people were leaving unemployment more often,

- unemployment spells got shorter with the rising level of education of the unemployed person.

b) referring to the unemployed registered in 2005 :

- generally speaking, the registered job seekers were leaving unemployment sooner than in the previous period of observation,

- $25 \%$ of the benefit recipients got deregistered after 3 months of job seeking, 50\% - after 6.9 months, $75 \%$ - after 13.3 months,

$-25 \%$ of those who were not entitled to the benefit got deregistered after 1.1 months of job seeking, $50 \%$ - after 2.8 months, and $75 \%$ - after 6.5 months,

- in terms of gender, age and education the situation in both observation periods was similar.

The mean values in Table 4 indicate differences in the duration of unemployment spells. The unemployment spells were longer in the case of the benefit recipients in each of the sub-groups and in both observation periods. However, in 2005-2007 the average period of registration was shorter than in 2001-2003.

Table 4. Mean values of the unemployment spells duration

\begin{tabular}{|l|c|c|c|c|}
\hline \multirow{3}{*}{ Groups } & \multicolumn{2}{|c|}{ 2001-2003 } & \multicolumn{2}{c|}{ 2005-2007 } \\
\cline { 2 - 5 } & \multicolumn{2}{|c|}{ mean } & \multicolumn{2}{c|}{ mean } \\
\cline { 2 - 5 } & benefit & no benefit & benefit & no benefit \\
\hline Total & 14.3 & 11.4 & 8.9 & 5.3 \\
\hline $\mathrm{K}$ & 15.0 & 11.4 & 9.6 & 5.0 \\
\hline $\mathrm{M}$ & 13.9 & 11.4 & 8.4 & 5.5 \\
\hline $\mathrm{W}_{1}$ & 13.6 & 10.0 & 7.2 & 5.0 \\
\hline $\mathrm{W}_{2}$ & 14.4 & 10.3 & 8.8 & 5.4 \\
\hline $\mathrm{W}_{3}$ & 14.8 & 13.6 & 9.2 & \\
\hline
\end{tabular}


Table 4 continued

\begin{tabular}{|l|c|c|c|c|}
\hline \multirow{3}{*}{ Groups } & \multicolumn{2}{|c|}{ 2001-2003 } & \multicolumn{2}{c|}{ 2005-2007 } \\
\cline { 2 - 5 } & \multicolumn{2}{|c|}{ mean } & \multicolumn{2}{c|}{ mean } \\
\cline { 2 - 5 } & benefit & no benefit & benefit & no benefit \\
\hline $\mathrm{W}_{4}$ & 14.6 & 13.0 & 10.8 & 7.2 \\
\hline $\mathrm{S}_{1}$ & 15.8 & 12.7 & 10.0 & 6.1 \\
\hline $\mathrm{S}_{2}$ & 14.8 & 11.6 & 8.2 & 5.5 \\
\hline $\mathrm{S}_{3}$ & 12.8 & 11.4 & 8.1 & 4.2 \\
\hline $\mathrm{S}_{4}$ & 12.6 & 9.1 & 9.4 & 3.9 \\
\hline $\mathrm{S}_{5}$ & 11.4 & 9.6 & 7.7 & \\
\hline
\end{tabular}

Source: own study based on the data from the Poviat Labour of Sulęcin.

Figure 2. Hazard of the unemployment exit in months (group 2001-2003)

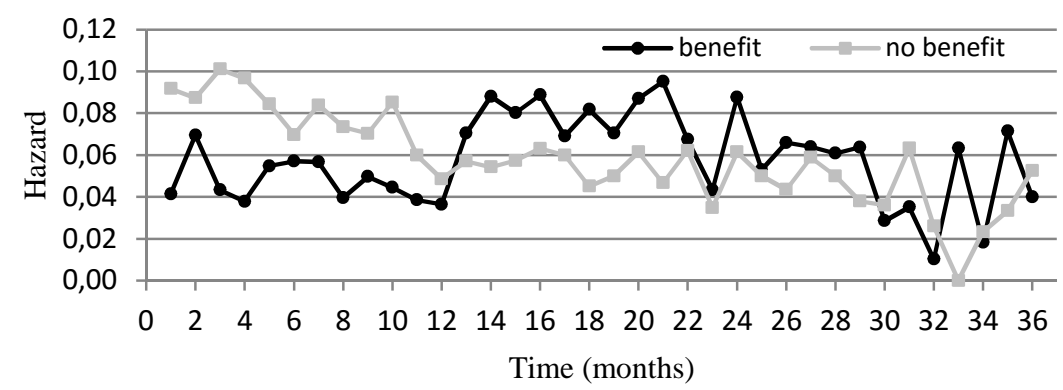

Source: own study based on the data from the Poviat Labour of Sulęcin.

Figure 3. Hazard of the unemployment exit in months (group 2005-2007)

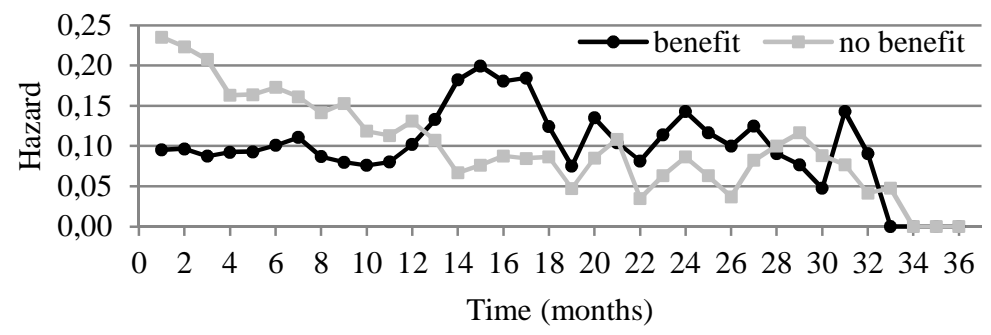

Source: own study based on the data from the Poviat Labour of Sulęcin. 
Figure 4. Hazard of the unemployment exit in months (group 2001-2003) by gender
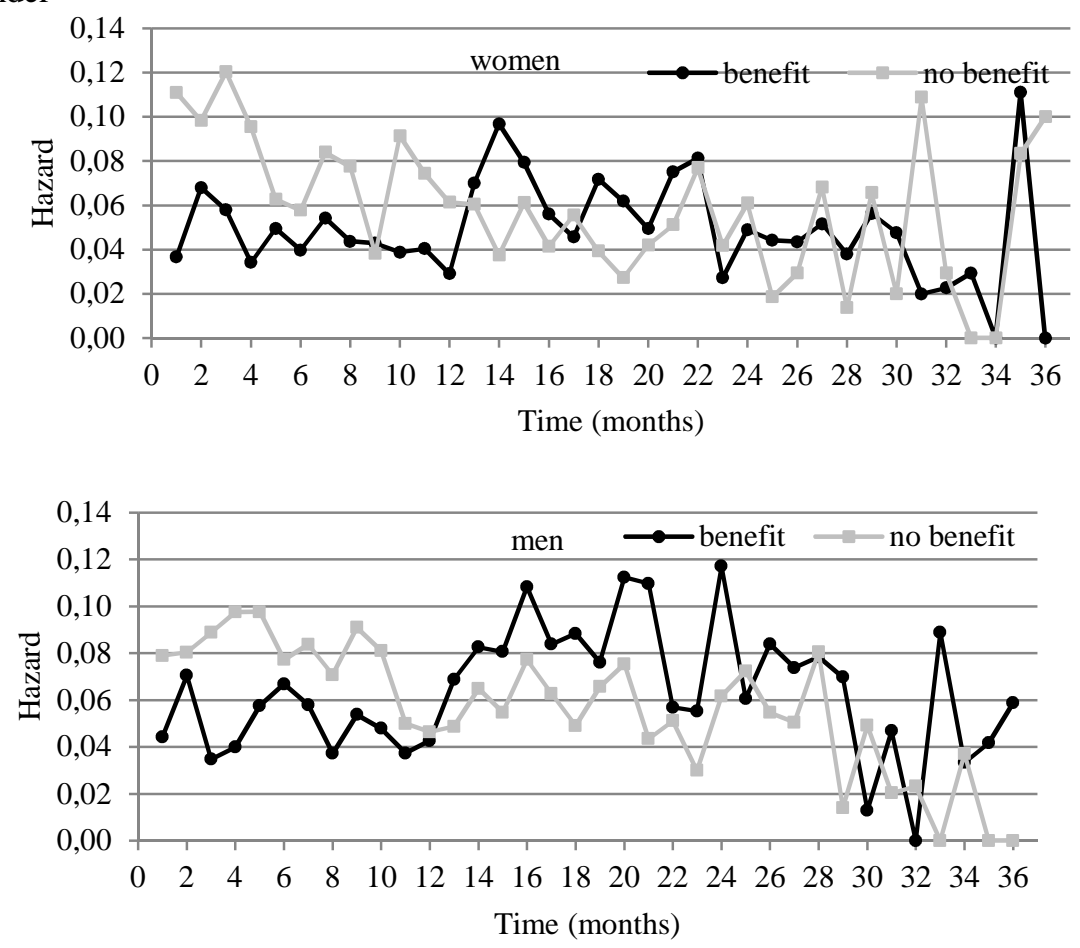

Source: own study based on the data from the Poviat Labour of Sulęcin.

Figure 5. Hazard of the unemployment exit in months (group 2005-2007) by gender

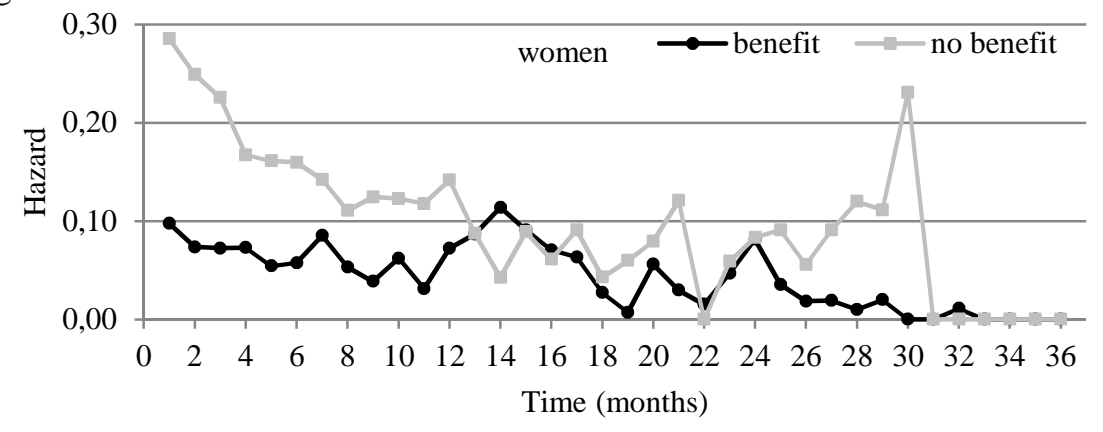


Figure 5 continued

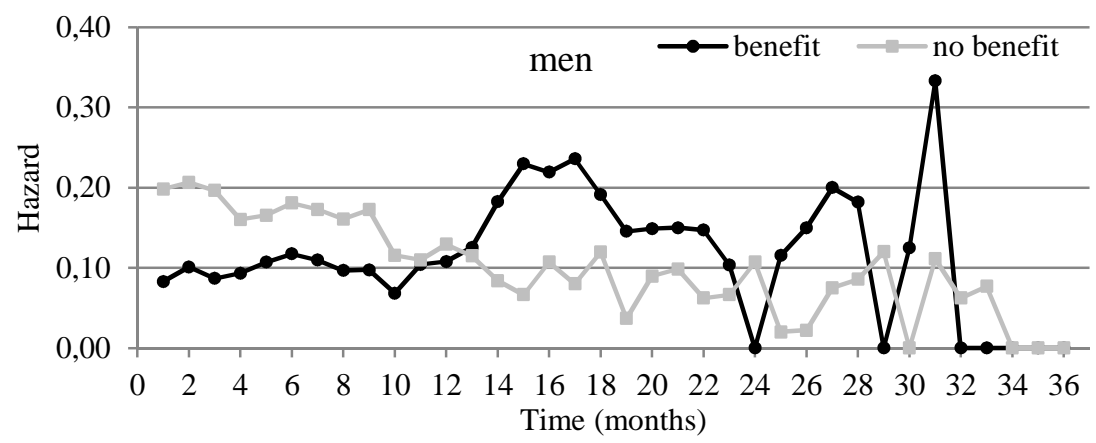

Source: own study based on the data from the Poviat Labour of Sulęcin.

The charts of hazards determined for the benefit recipients and for the job seekers who were not entitled to benefits in both observation periods show the absence of proportionality (Figures 2 and 3). In the first 12 months we could see higher intensity of register leaving by the unemployed who were not entitled to the benefits than by the benefit recipients In the 13th month the situation was reversed. A similar tendency took place in the gender, age and education sub-groups (see exemplary presentations of the age sub-groups in Figures 4 and 5). Therefore, in the Cox regression model (3) for the function (4) we adopted $t_{0}=13$. In the first period (up to 13 months) the values of hazard ratios were less than 1 , which means that the intensity of the register leaving by the benefit recipients was lower than in the case of the remaining unemployed (Figures 6 and 7). When determining the hazard ratio, the peer group was the group average, which was marked in Figures 6 and 7 with a line in bold. After 13 months (period II) the situation reversed in most of the sub-groups (excluding the insignificant ones). The parameter estimators, including errors and the significance level for the model in question, are presented in Tables 5 and 6.

Table 5. Results of estimating parameters in Cox models (period 2001-2003)

\begin{tabular}{|c|c|c|c|c|}
\hline \multirow[t]{2}{*}{ Groups } & \multicolumn{2}{|c|}{$\begin{array}{l}\text { Parameters estimates } \\
\text { (standard error) }\end{array}$} & \multicolumn{2}{|c|}{$p$} \\
\hline & $\beta$ & $\delta$ & $\beta$ & $\delta$ \\
\hline Total & $-0.5077(0.0509)$ & $0.8458(0.0897)$ & 0.0000 & 0.0000 \\
\hline $\mathrm{K}$ & $-0.5907 \quad(0.0834)$ & $0.8474(0.1495)$ & 0.0000 & 0.0000 \\
\hline $\mathrm{M}$ & $-0.4575(0.0643)$ & $0.8403(0.1124)$ & 0.0000 & 0.0000 \\
\hline $\mathrm{W}_{1}$ & $-0.6562(0.0917)$ & $1.1669(0.1651)$ & 0.0000 & 0.0000 \\
\hline
\end{tabular}


Table 5 continued

\begin{tabular}{|c|c|c|c|c|}
\hline \multirow{2}{*}{ Groups } & \multicolumn{2}{|c|}{$\begin{array}{c}\text { Parameters estimates } \\
\text { (standard error) }\end{array}$} & \multicolumn{2}{c|}{$\boldsymbol{p}$} \\
\cline { 2 - 5 } & $\boldsymbol{\beta}$ & $\boldsymbol{\delta}$ & $\boldsymbol{\beta}$ & $\boldsymbol{\delta}$ \\
\hline $\mathrm{W}_{2}$ & $-0.6510(0.0965)$ & $0.9166(0.1751)$ & 0.0000 & 0.0000 \\
\hline $\mathrm{W}_{3}$ & $-0.3243(0.1055)$ & $0.8082(0.1776)$ & 0.0021 & 0.0000 \\
\hline $\mathrm{W}_{4}$ & $-0.2497(0.1264)$ & $0.2148(0.2168)$ & 0.0482 & 0.3218 \\
\hline $\mathrm{S}_{1}$ & $-0.6265(0.1051)$ & $1.2011(0.1802)$ & 0.0000 & 0.0000 \\
\hline $\mathrm{S}_{2}$ & $-0.5409(0.0764)$ & $0.7704(0.1292)$ & 0.0000 & 0.0000 \\
\hline $\mathrm{S}_{3}$ & $-0.1564(0.2243)$ & $-0.0009(0.4262)$ & 0.4857 & 0.9984 \\
\hline $\mathrm{S}_{4}$ & $-0.5343(0.1083)$ & $0.7934(0.2134)$ & 0.0000 & 0.0002 \\
\hline $\mathrm{S}_{5}$ & $-0.3606(0.2730)$ & $0.8288(0.5390)$ & 0.1865 & 0.1241 \\
\hline
\end{tabular}

Source: own study based on the data from the Poviat Labour of Sulęcin, Statistica 10.

Figure 6. Relative hazard of the unemployment exit in months (group 2001-2003)

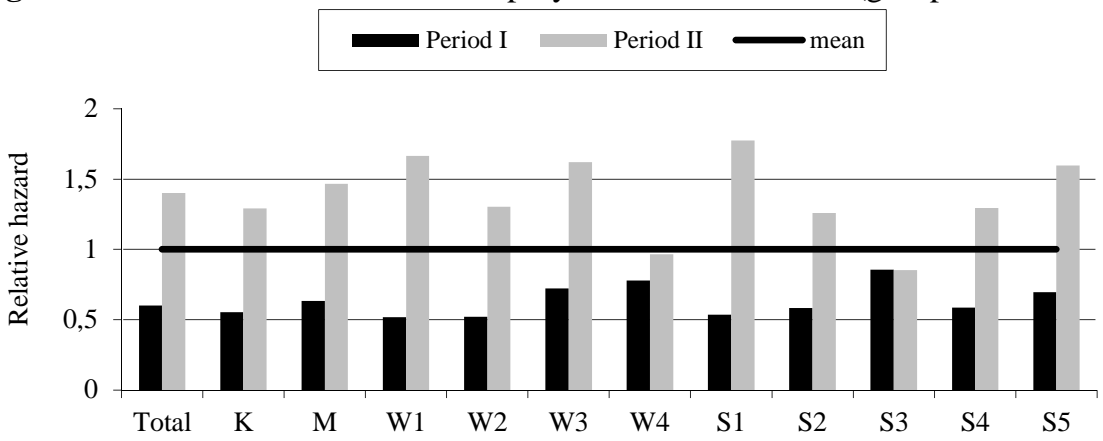

Source: own study based on the data from the Poviat Labour of Sulęcin.

Table 6. Results of estimating parameters in Cox models (period 2005-2007)

\begin{tabular}{|c|c|c|c|c|}
\hline \multirow{2}{*}{ Group } & \multicolumn{2}{|c|}{$\begin{array}{c}\text { Parameters estimates } \\
\text { (standard error) }\end{array}$} & \multicolumn{2}{c|}{$\boldsymbol{\beta}$} \\
\cline { 2 - 5 } & $\boldsymbol{\beta}$ & $\boldsymbol{\delta}$ & $\boldsymbol{\beta}$ & $\boldsymbol{\delta}$ \\
\hline Total & $-0.6895(0.0416)$ & $1.3501(0.1078)$ & 0.0000 & 0.0000 \\
\hline $\mathrm{K}$ & $-0.7900(0.0677)$ & $1.2685(0.1695)$ & 0.0000 & 0.0000 \\
\hline $\mathrm{M}$ & $-0.6202(0.0529)$ & $1.4411(0.1409)$ & 0.0000 & 0.0000 \\
\hline $\mathrm{W}_{1}$ & $-0.6735(0.0741)$ & $1.0328(0.2377)$ & 0.0000 & 0.0000 \\
\hline $\mathrm{W}_{2}$ & $-0.7485(0.0755)$ & $1.5064(0.2070)$ & 0.0000 & 0.0000 \\
\hline $\mathrm{W}_{3}$ & $-0.6956(0.0981)$ & $1.2510(0.2399)$ & 0.0000 & 0.0000 \\
\hline $\mathrm{W}_{4}$ & $-0.6552(0.0992)$ & $1.3471(0.2127)$ & 0.0000 & 0.0000 \\
\hline $\mathrm{S}_{1}$ & $-0.7374(0.0897)$ & $1.5662(0.2017)$ & 0.0000 & 0.0000 \\
\hline
\end{tabular}


Table 6 continued

\begin{tabular}{|c|c|c|c|c|}
\hline \multirow{2}{*}{ Group } & \multicolumn{2}{|c|}{$\begin{array}{c}\text { Parameters estimates } \\
\text { (standard error) }\end{array}$} & \multicolumn{2}{c|}{$\boldsymbol{\beta}$} \\
\cline { 2 - 5 } & $\boldsymbol{\beta}$ & $\boldsymbol{\delta}$ & $\boldsymbol{\beta}$ & $\boldsymbol{\delta}$ \\
\hline $\mathrm{S}_{2}$ & $-0.5529(0.0631)$ & $1.2500(0.1656)$ & 0.0000 & 0.0000 \\
\hline $\mathrm{S}_{3}$ & $-0.8764(0.1698)$ & $2.4630(0.6007)$ & 0.0000 & 0.0000 \\
\hline $\mathrm{S}_{4}$ & $-0.9511(0.0866)$ & $1.2330(0.2586)$ & 0.0000 & 0.0000 \\
\hline $\mathrm{S}_{5}$ & $-0.6269(0.1929)$ & $0.1347(0.6175)$ & 0.0012 & 0.8273 \\
\hline
\end{tabular}

Source: own study based on the data from the Poviat Labour of Sulęcin, Statistica 10.

Figure 7. Relative hazard of the unemployment exit in months (group 2005-2007)
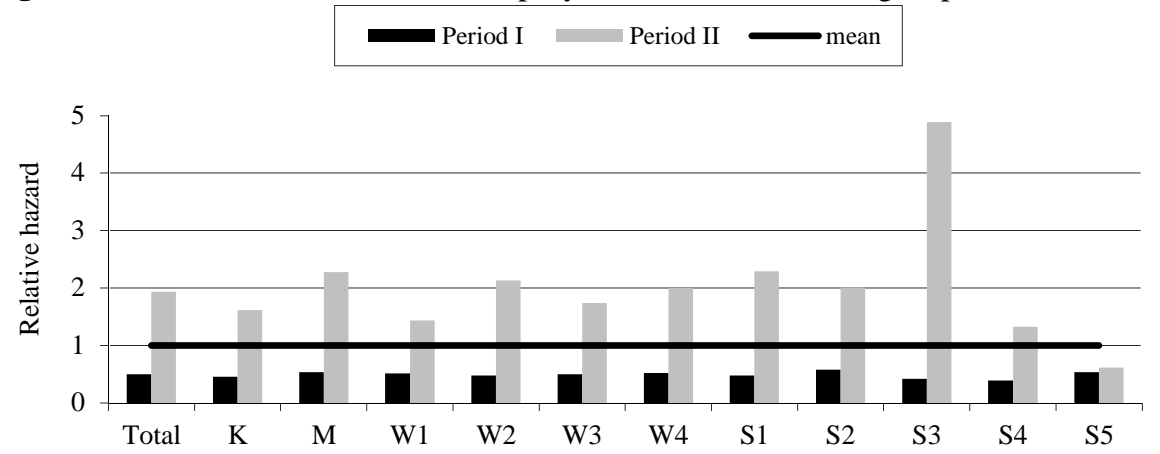

Source: own study based on the data from the Poviat Labour of Sulęcin.

\section{Conclusions}

The study confirmed the research hypotheses. The fact of receiving the unemployment benefit extended the unemployment spells in both periods of observation. The loss of the right to the benefit increased the probability of deregistration in each sub-group. The fact of receiving the benefit reduced the likelihood of leaving the register in the first 13 months following the registration in both 2001-2001 and 2005-2007 observation periods. Poland's accession to the European Union and the access to funding from projects implemented by the Poviat Labour Office in Sulęcin had an effect on reducing the registered unemployment spells and on the intensity of unemployment exit. Since 2004 the PLO have implemented numerous pro- 
jects financed by the $\mathrm{EU}^{6}$ that aimed at improving the situation of job seekers on the job market. The projects targeted specific groups of job seekers, e.g. those affected by long-term unemployment, young people, women or those who were planning to start their own business.

\section{References}

Bieszk-Stolorz, B. (2013). Analiza historii zdarzeń w badaniu bezrobocia. Szczecin: Volumina.pl Daniel Krzanowski.

Bieszk-Stolorz, B., \& Markowicz, I. (2012). Modele regresji Coxa $w$ analizie bezrobocia. Warszawa: CeDeWu.

Card, D. E., \& Levine, P. B. (2000). Extended Benefits and the Duration of UI Spells: Evidence from the New Jersey Extended Benefit Program. Journal of Public Economics, 78(1-2). http://dx.doi.org/10.1016/S0047-2727(99)00113-9.

Hahn, J., Todd, P., \& Van der Klaauw, W. (2001). Identyfication and Estimation of Treatment Effects with a Regression-Discontinuity Design. Econometrica, 69(1). http://dx.doi.org/10.1111/1468-0262.00183.

Han, A., \& Hausman, J. A. (1990). Flexible Parametric Estimation of Duration and Competing Risk Models. Journal of Applied Econometrics, 5(1). http://dx.doi.org/10.1002/jae.3950050102.

Hughes, J. J, \&Perlman, R. (1984). The Economics of Unemployment: A Comparative Analysis of Britain and the United States. New York: Cambridge University Press.

Hunt, J. (1995). The Effect of Unemployment Compensation on Unemployment Duration in Germany. Journal of Labor Economics, 13(1). http://dx.doi.org/10. $1086 / 298369$.

Kaplan, E. L., \& Meier, P. (1958). Nonparametric estimation from incomplete observations. Journal of the American Statistical Association, 53(282). http://dx.doi.org/10.2307/2281868.

Katz, L. (1986). Layoffs, recall and the duration of unemployment. Cambridge: National Bureau of Economic Research, Working Paper no. 1825.

Katz, L., \& Meyer, B. (1990). The Impact of the Potential Duration of Unemployment Benefits on the Duration of Unemployment. Journal of Public Economics, 41(1). http://dx.doi.org/10.1016/0047-2727(92)90056-L.

Lalive, R. (2007). Unemployment Benefits, Unemployment Duration, and PostUnemployment Jobs: A Regression Discontinuity Approach. The American Economic Review, 97(2). http://dx.doi.org/10.1257/aer.97.2.108

Meyer, B. D. (1990). Unemployment Insurance and Unemployment Spells. Econometrica, 58(4). http://dx.doi.org/10.2307/2938349.

\footnotetext{
${ }^{6}$ The examples of the projects: Internship Abroad - an Opportunity for the Youth in the Poviat of Sulecin, No to Long-term Unemployment, Active Start for Young People, Career Woman - Independent Woman.
} 
Moffitt, R. A. (1985). Unemployment Insurance and Distribution of Unemployment Spells. Journal of Econometrics, 28(1). http://dx.doi.org/10.1016/03044076(85)90068-5.

Mortensen D. T. (1977), Unemployment Insurance and Job Search Decisions. Industrial and Labor Relations Review, 30 (4). http://dx.doi.org/10.2 307/2523111.

Nickell, S. (1979). The Effect of Unemployment and Related Benefits on the Duration of Unemployment. Economic Journal, 89(353). http://dx.doi.org/10. 2307/2231405.

Nickell, S., \& Layard, R. (1999). Labor Market Institutions and Economic Performance. In O. Ashenfelter, \& Card O. (Eds), Handbook of Labor Economics, Vol. 3, Amsterdam: Elsevier.

Røed, K., Zhang, T. (2003). Does Unemployment Compensation Affect Unemployment Duration? The Economic Journal, 113(484). http://dx.doi.org/10. 1111/1468-0297.00086.

Schmieder, J. F., von Wachter, T, \& Bender, S. (2012). The Effects of Extended Unemployment Insurance Over the Business Cycle: Evidence from Regression Discontinuity Estimates Over 20 Years. The Quarterly Journal of Economics, 127(2). http://dx.doi.org/10.1093/qje/qjs010. 
